\title{
ANALISIS KASUS COVID-19 BERBASIS GOOGLE TRENDS DI INDONESIA PADA MASA NEW NORMAL
}

\author{
(Case Analysis Of COVID-19 Based On Google Trends In Indonesia At The New Normal \\ Time)
}

\author{
Yoga Dwi Nugroho', Ignatius Sandyawan² \\ Badan Pusat Statistik ${ }^{1}$ \\ Badan Pusat Statistik ${ }^{2}$ \\ Jl. Dr. Sutomo 6-8 Jakarta \\ E-mail: yoga.dwin@bps.go.id, ignatius.sandyawan@bps.go.id
}

\begin{abstract}
ABSTRAK
Pandemi COVID-19 yang menginfeksi hampir seluruh negara di dunia menimbulkan dampak yang kompleks pada berbagai sektor baik ekonomi, kesehatan, pendidikan dan kehidupan sosial masyarakat. Untuk itu, penting bagi pemerintah mendapatkan informasi mengenai perhatian dan kebutuhan masyarakat sehingga kepanikan dan kebutuhan masyarakat (preventing illness) dapat diberikan solusi. Penelitian ini menggunakan data real time Google Trends sebagai variabel bebas dan kasus terkonfirmasi positif COVID19 sebagai variabel terikat yang akan dianalisis menggunakan analisis data panel statis fixed effect method (FEM) dan analisis data panel dinamis (GMM regression estimation) dengan tujuan untuk menganalisis perkembangan kasus COVID-19 pada seluruh provinsi di Indonesia yang dikaitkan dengan (banyaknya) ketertarikan masyarakat terhadap informasi terkait COVID-19 baik metode dan bahan yang digunakan untuk menekan penyebaran COVID-19 seperti masker, desinfektan, hand sanitizer, Alat Pelindung Diri (APD) maupun informasi gejala COVID-19 dan mobilitas masyarakat. Selain itu, penelitian ini juga bertujuan untuk menganalisis efek individu setiap provinsi dan efek waktu yang nantinya akan dibandingkan dan dilihat asosiasinya dengan kasus positif COVID-19 dan hasil pencarian gejala COVID-19. Hasilnya pencarian informasi terkait dengan COVID-19 memiliki pengaruh negatif terhadap perkembangan kasus COVID-19. Terdapat 7 variabel yang digunakan dan 6 variabel mengenai informasi yang dicari terkait COVID-19 yang signifikan menggunakan analisis data panel FEM SUR yaitu, APD, korona, hand sanitizer, gejala corona, desinfektan, masker. Adanya efek dinamis dari variabel dependen maka digunakan regresi data panel dinamis FD-GMM yang menunjukkan data estimasi lebih baik dan terdapat 6 variabel yang signifikan yaitu, APD, korona, hand sanitizer, gejala corona, desinfektan, dan lag variabel dependen.
\end{abstract}

Kata kunci: COVID-19, Google Trends, New Normal, Panel, GMM

\begin{abstract}
The COVID-19 pandemic, which has infected almost all countries in the world, has a complex impact on various sectors, including economy, health, education and social life. For this reason, it is important for the government to get information about the people's concerns and needs so that panic and community needs (preventing disease) can be given a solution. This study uses Google Trends real time data as independent variables and positive confirmed cases of COVID-19 as variables to be analyzed using statistical fixed effect method (FEM) panel data analysis and dynamic panel data analysis (GMM regression estimation) with the aim of analyzing case developments. COVID-19 in all provinces in Indonesia which are very close to (the large number) of public interest in information related to COVID-19, both the methods and materials used for the spread of COVID-19 such as masks, disinfectants, hand sanitizers, Personal Protective Equipment (PPE) and information. symptoms of COVID-19 and community mobility. In addition, this study also aims to analyze the individual effects of each province and the time effects which will be compared and seen in association with positive cases of COVID-19 and the results of examining COVID-19 symptoms. As a result, interest of information related to COVID-19 has a negative effect on the increasing of COVID-19 cases. There are 7 variables used and 6 variables regarding the information sought regarding significant COVID-19 using the FEM SUR panel data analysis, namely, PPE, corona, hand sanitizer, corona symptoms, disinfectants, masks. With the dynamic effect of the dependent variable, the dynamic panel data regression FD-GMM is used which shows better estimation and there are 6 significant variables PPE, corona, hand sanitizer, corona symptoms, disinfectants, and lag of the dependent variable.
\end{abstract}


Keywords: COVID-19, Google Trends, New Normal, Panel, GMM

\section{PENDAHULUAN}

Pandemi COVID-19 merupakan pandemi yang telah menyebar dan menginfeksi hampir seluruh negara di dunia tak terkecuali dengan Indonesia. Sejak pertama kali teridentifikasi di Indonesia pada awal bulan Maret, virus COVID-19 sudah menyebar dan menginfeksi ke seluruh provinsi di Indonesia. Adanya pandemi COVID-19 telah memberikan dampak yang kompleks pada berbagai sektor baik ekonomi, kesehatan, pendidikan dan kehidupan sosial masyarakat. Hal ini membuat pemerintah Indonesia melakukan berbagai kebijakan untuk mengurangi laju penyebaran virus COVID-19 ini sampai akhirnya pemerintah Indonesia menyatakan masa normal baru (New Norma) pada tanggal 5 Juni 2020. Hal ini berimplikasi pada aktivitas masyarakat yang mulai berangsur-angsur berjalan kembali seperti semula sebelum pandemi.

Pada masa pandemi ini, penting bagi pemerintah untuk mengetahui data potensial yang mampu menunjukkan perhatian dan kebutuhan masyarakat sehingga kepanikan dan kebutuhan masyarakat (preventing illness) dapat diberikan solusi dan kebijakan yang tepat. Salah satu sumber data terpercaya yang dapat digunakan untuk kebutuhan analisis ini adalah Google Trends. Google Trends adalah platform untuk mengetahui trend suatu kata yang dicari di dalam Google. Data ini merupakan big data (salah satu big data) sebagai sumber data terpercaya yang secara jelas menangkap (sentiment) respon masyarakat (public response) atas pandemi COVID-19.

Atas latar belakang tersebut, penelitian ini bertujuan untuk menganalisis perkembangan kasus COVID-19 pada seluruh provinsi di Indonesia yang dikaitkan dengan (banyaknya) ketertarikan masyarakat terhadap informasi terkait COVID-19 baik metode dan bahan yang digunakan untuk menekan penyebaran COVID-19 seperti masker, desinfektan, hand sanitizer, Alat Pelindung Diri (APD) maupun informasi gejala COVID-19 dan mobilitas masyarakat. Selain itu, penelitian ini juga bertujuan untuk menganalisis efek individu setiap provinsi dan efek waktu yang nantinya akan dibandingkan dan dilihat asosiasinya dengan kasus positif COVID-19 dan hasil pencarian gejala COVID-19.

\section{METODE}

Penelitian ini menggunakan data dari Google Trends dengan kata kunci apd, corona, COVID, desinfektan, korona, masker, hand sanitizer, gejala korona, dan gejala COVID dari tanggal 5 Juni 2020 hingga 26 Juli 2020. Data lainnya yang digunakan adalah data penambahan kasus COVID-19 dari laman https://data.covid19.go.id. Metode analisis yang digunakan adalah sebagai berikut :

\section{Fixed Effect Model (FEM)}

FEM merupakan salah satu model data panel statis. FEM memiliki pola yang tidak acak atau korelasi antara efek individu dan variabel independen dengan $x_{i t}$ sehingga komponen error dari efek individu dan waktu dapat menjadi bagian dari intercept. FEM memiliki kelebihan untuk menangkap karakteristik beda antarindividu (Gujarati dan Porter, 2008)

Model umum FEM merupakan pengembangan dari pooled, yaitu

$$
y_{i t}=a+\boldsymbol{X}_{i t}^{\prime} \boldsymbol{\beta}+\mathrm{u}_{i t}
$$

dengan $\mathrm{u}_{\mathrm{it}}=\mu_{\mathrm{i}}+\mathrm{v}_{\mathrm{it}}$, maka model umum persamaan (1) menjadi

$$
\begin{aligned}
& y_{i t}=a+\boldsymbol{X}_{i t}^{\prime} \boldsymbol{\beta}+\mu_{\mathrm{i}}+\mathrm{v}_{\mathrm{it}} \\
& y_{i t}=\left(a+\mu_{\mathrm{i}}\right)+\boldsymbol{X}_{i t}^{\prime} \boldsymbol{\beta}+\mathrm{v}_{\mathrm{it}} \\
& y_{i t}=a_{i}+\boldsymbol{X}_{i t}^{\prime} \boldsymbol{\beta}+\mathrm{v}_{\mathrm{it}}
\end{aligned}
$$


sehingga model umum FEM menjadi sebagai berikut

$$
y_{i t}=a_{i}+\boldsymbol{X}_{i t}^{\prime} \boldsymbol{\beta}+v_{i t}
$$

Keterangan:

$y_{\text {it }} \quad$ : variabel dependen individu ke-i periode ke-t

$a \quad$ : intercept gabungan

$\mu_{\mathrm{i}} \quad$ : error individu ke-i

$a_{i} \quad$ : intercept individu ke-i

$\boldsymbol{\beta} \quad$ : vektor slope dari variabel independen berukuran $\mathrm{KX} 1$

$\boldsymbol{X}_{i t}^{\prime}$ : vektor dari variabel independen ke-i periode ke-t berukuran $1 \times \mathrm{K}$

$v_{\text {it }} \quad$ : error individu ke-i periode ke-t

$\mathrm{K}$ : jumlah variabel independen

i : individu, $\mathrm{i}=1,2, \ldots, \mathrm{N}$

$\mathrm{t} \quad$ : periode waktu, $\mathrm{t}=1,2, \ldots, \mathrm{T}$

\section{Generalized Method of Momen (GMM) Regression Estimation}

GMM regression estimation atau panel dinamis adalah metode regresi yang menambahkan lag variabel dependen untuk dijadikan sebagai variabel independen. Persamaan model panel dinamis adalah sebagai berikut :

$$
y_{i t}=\delta y_{i, t-1}+\mathbf{X}^{\prime}{ }_{i t} \boldsymbol{\beta}+\mathbf{u}_{i t}
$$

dimana

$i: 1,2, \ldots, \mathrm{N}$

$t: 2,3, \ldots, T$

Untuk $\delta$ merupakan skalar dan matriks berukuran, $\beta$ merupakan matriks berukuran $\mathrm{Kx1}$ dan $y \mathrm{i}, \mathrm{t}-1$ merupakan variabel terikat individu ke-i periode ke-(t-1). Asumsi pada one-way error component model, yaitu:

$$
u_{i t}=\mu_{i}+v_{i t}
$$

$\mu i$ merupakan efek individu yang diasumsikan $\mu i \sim \operatorname{IID}(0,2)$ dan vit merupakan error term yang diasumsikan vit $\operatorname{IID}(0, \sigma \mu 2)$ dan vit saling bebas satu dengan yang lainnya.

\section{Uji Chow}

Chow Test adalah pengujian untuk memilih apakah model yang digunakan Pooled Least Square atau Fixed Effect Model. Dalam pengujian ini dilakukan dengan hipotesis sebagai berikut (Baltagi, 2011) :

$$
H_{0}: \mu_{1}=\mu_{2}=\cdots=\mu_{N-1}=0 \text { (Pooled Least Square) }
$$

$H_{1}$ : minimal ada satu $\mu_{i} \neq 0 ; i=1,2, \cdots, N-1$ (Fixed Effect Model)

Adapun statistik uji dari uji Chow menggunakan F Statistik seperti yang dirumuskan oleh Chow.

$$
\text { CHOW }=\frac{(\text { RRSS }-U R S S) /(N-1)}{(\text { URSS }) /(N T-N-K)}
$$

Keterangan:

RRSS : Restricted Residual Sum Square

URSS : Unrestricted Residual Sum Square

$\mathrm{N}$ : Jumlah data cross section

$\mathrm{T}$ : Jumlah data time series

$\mathrm{K}$ : Jumlah variabel independen

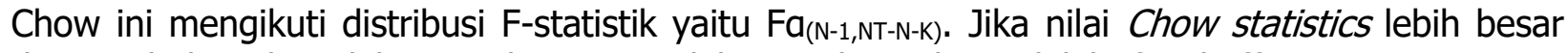
dari F-tabel, maka tolak $H_{0}$, sehingga model yang digunakan adalah fixed effect.

\section{Uji Hausman}


Dalam memilih apakah fixed atau random effect yang lebih baik, dilakukan pengujian terhadap asumsi ada tidaknya korelasi antara regresor (variabel independen) dan efek individu. Untuk menguji asumsi ini dapat digunakan Uji Hausman. Hipotesis yang diuji adalah sebagai berikut (Baltagi, 2011):

$H_{0}: E\left(u_{i t} \mid x_{i t}\right)=0$ (REM adalah model yang tepat)

$H_{1}: E\left(u_{i t} \mid x_{i t}\right) \neq 0$ (FEM adalah model yang tepat)

Kemudian, nilai statistik uji Hausman dibandingkan dengan nilai statistik Chi square. Statistik Hausman dirumuskan dengan:

$$
H=\left(\beta_{F E M}-\beta_{R E M}\right)^{\prime}\left(M_{F E M}-M_{R E M}\right)^{-1}\left(\beta_{F E M}-\beta_{R E M}\right) \sim \chi_{(k)}^{2}
$$

dimana:

M : matriks kovarian untuk parameter $\beta$

B : koefisien parameter dari model

$\mathrm{k} \quad$ : adalah derajat bebas

Jika nilai $\mathrm{H}$ lebih besar dari $\mathrm{X} 2$ tabel, maka cukup bukti untuk melakukan penolakan terhadap $H_{0}$ sehingga model yang digunakan adalah model fixed effect begitu juga sebaliknya.

\section{Uji Langrange Multiplier (Uji BPLM)}

Langrange Multiplier adalah uji untuk mengetahui apakah model random effect (REM) atau model common effect (PLS/CEM) yang paling tepat digunakan. Uji signifikansi random effect ini dikembangkan oleh Breusch Pagan. Metode Breusch Pagan untuk uji signifikansi random effect didasarkan pada nilai residual dari metode OLS. Adapun hipotesis untuk melakukan uji LM adalah sebagai berikut (Baltagi, 2011):

$H_{0}: \sigma_{\mu}^{2}=0$ (CEM/PLS adalah model yang tepat)

$H_{1}: \sigma_{\mu}^{2}>0$ (REM adalah model yang tepat)

dengan statistik ujinya sebagai berikut

$$
B P_{L M}=\frac{N T}{2(T-1)}\left(\frac{\sum_{i=1}^{N}}{\sum_{i=1}^{N}}\left(\begin{array}{lll}
\sum_{t=1}^{T} & \sum_{i t=1}^{T} & \hat{u}_{i t}^{2}
\end{array}-1\right)^{2}\right.
$$

daerah penolakan untuk uji LM ketika BPLM $>\chi_{\alpha, 1}^{2}$. Jika $H_{0}$ ditolak maka model REM adalah model yang tepat. Sedangkan jika gagal tolak $H_{0}$ berarti model yang tepat digunakan adalah model pooled least square.

\section{Akaike's Information Criterion (AIC)}

AIC adalah salah satu cara untuk menentukan model terbaik dari beberapa model yang telah dibentuk. Semakin kecil nilai AIC maka model tersebut semakin baik. Penghitungan AIC didasarkan pada metode maximum likelihood estimation (MLE). Rumus AIC adalah sebagai berikut :

$$
A I C=-2 \ln (L)+2 k
$$

dimana:

$\mathrm{L}$ : nilai dari likelihood

$\mathrm{k}$ : jumlah parameter estimasi.

\section{Schwarz Criterion (SC)}

SC atau sering disebut juga Bayesian Information Criterion (BIC) adalah kriteria untuk menentukan model terbaik dari beberapa model yang ada. SC didasarkan pada fungsi likelihood dan terkait erat dengan AIC. Sama seperti AIC, semakin kecil nilai SC maka semakin baik model tersebut. Dalam pembentukan model, penambahan parameter dapat menambah likelihood akan tetapi akan menimbulkan overfitting pada model. SC dapat mengatasi masalah penambahan parameter tersebut. Rumus SC adalah sebagai berikut : 


$$
S C=-2 \ln (L)+2 \ln (N) k
$$

dimana:

L : nilai dari likelihood

$\mathrm{k}$ : jumlah parameter estimasi.

$\mathrm{N}$ : jumlah observasi

\section{$R^{2}$ adjusted}

$\mathrm{R}^{2}$ adjusted menghitung proporsi variasi yang dijelaskan hanya oleh variabel independen yang dapat menjelaskan variabel dependen. Sama seperti SC, $\mathrm{R}^{2}$ adjusted dapat digunakan untuk menghindari overfitting. Nilai $\mathrm{R}^{2}$ adjusted akan memberikan penalti jika penambahan variabel independen tidak tidak menambah proporsi variasi yang dijelaskan secara signifikan.

Rumus $\mathrm{R}^{2}$ adjusted dapat dituliskan sebagai berikut :

$$
R^{2} \text { adjusted }=1-\frac{\left(1-R^{2}\right)(N-1)}{N-p-1}
$$

Keterangan :

$\mathrm{p}$ : jumlah independen variabel

$\mathrm{N}$ : total observasi

\section{HASIL DAN PEMBAHASAN}

Pandemi COVID-19 menginfeksi banyak sekali orang di Indonesia, sampai dengan 17 September 2020 lebih dari 232.514 orang terinfeksi virus ini. Adapun penyebaran kasus positif COVID-19 jika dianalisis menurut provinsi akan memberikan gambaran yang jelas provinsi dengan jumlah kasus terbanyak. Berikut merupakan 10 provinsi di Indonesia dengan kasus COVID-19 terbanyak.

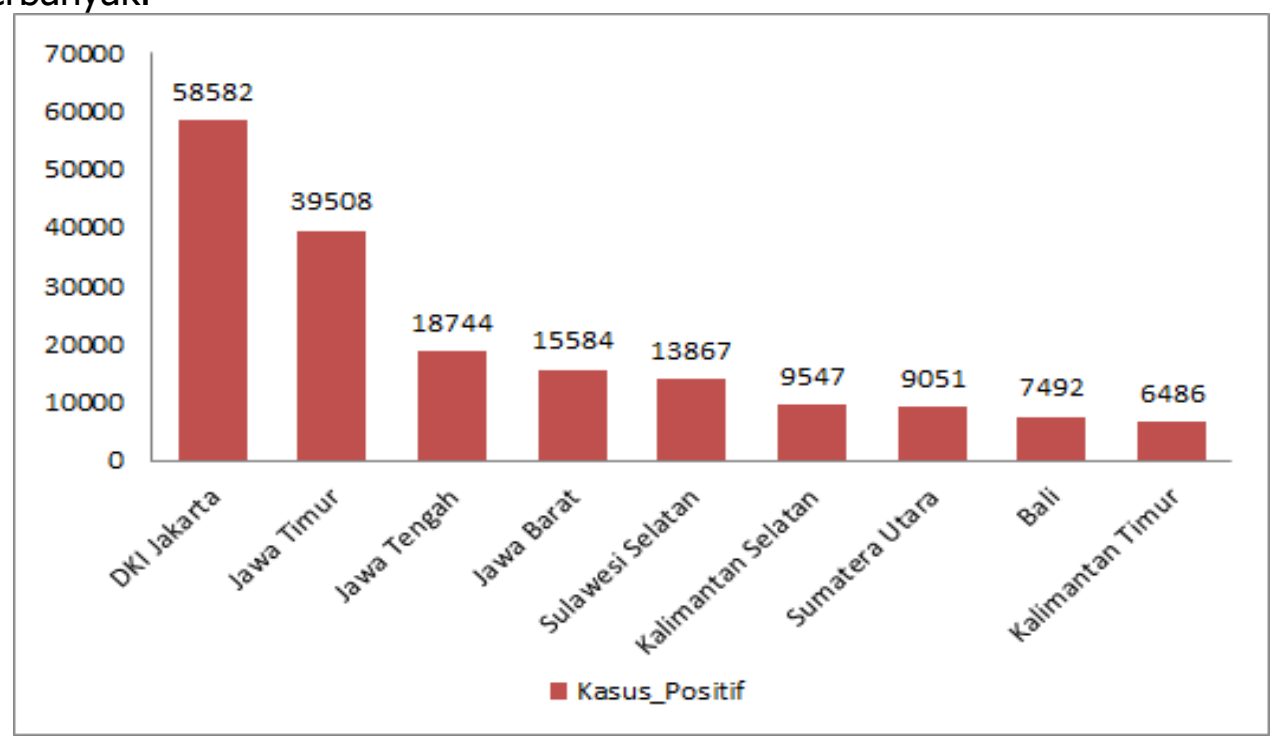

Sumber: Badan Nasional Penanggulangan Bencana (https://bnpb-inacovid19.hub.arcgis.com/)

Gambar 1. 10 provinsi di Indonesia dengan kasus COVID-19 paling banyak

Berdasarkan gambar diatas DKI Jakarta merupakan provinsi paling banyak kasus orang terinfeksi virus corona dengan jumlah 58.582 orang terinfeksi. Provinsi DKI Jakarta merupakan provinsi dimana kasus pertama corona ditemukan. Adanya virus corona yang sudah menyebar di Indonesia menyebabkan pemerintah melakukan berbagai kebijakan. Yunus dan Rezki (2020) menyebutkan pemerintah dengan sigap mengambil tindakan, misalnya Gubernur DKI Jakarta yang mengeluarkan Pergub No.41 tahun 2020 tentang Pengenaan Sanksi Terhadap Pelanggaran Pelaksanaan Pembatasan Sosial Berskala Besar Dalam Penanganan Coronavirus 
Disease 2019 (Covid-19) Di Provinsi Daerah Khusus Ibukota Jakarta dan Pergub No.51 tahun 2020 tentang Pelaksanaan Pembatasan Sosial Berskala Besar Pada Masa Transisi Menuju Masyarakat, Sehat, Aman dan Produktif. Disisi lain, selain DKI Jakarta provinsi-provinsi besar lain di Pulau Jawa seperti, Jawa Timur, Jawa Tengah dan Jawa Barat turut menjadi provinsi paling banyak kasus positif corona ditemukan dengan kasus secara berturut-turut sebanyak $39.508,18.744,15.584$ kasus dan tentunya pemerintah daerah tersebut harus sigap dalam menerapkan kebijakan yang tepat.

Dengan keadaan yang semakin sulit dan kasus positif corona yang semakin naik, pemerintah dalam menerapkan kebijakan harus hati-hati, cermat dan bijak. Hal ini dapat dilakukan salah satunya dengan berpedoman pada data yang sudah tersebar luas di internet (big data), mudah diakses namun dapat dipertanggungjawabkan. Salah satu big data ini adalah data Google Trends. Riyanto (2014) menjelaskan lebih lanjut bahwa Google Trends adalah situs web yang dimiliki Google.Inc yang berisi trend penggunaan kata kunci di website mesin pencari google dan berita yang sedang trend. Salah satu manfaat google trend adalah untuk research (riset) dan menunjukkan keyword yang sedang dicari oleh pengguna internet. Tentunya hal ini dapat dipertimbangkan pemerintah mengenai hal/fokus yang menjadi perhatian masyarakat dalam situasi pandemi COVID-19 ini yang selanjutnya dapat diterapkan kebijakan yang sesuai.

Selanjutnya, untuk menganalisis kasus Covid-19 dengan ketertarikan informasi yang dicari masyarakat berhubungan dengan Covid maka dilakukan analisis menggunakan data panel.

Tabel 1. Hasil Regresi Data Panel Statis FEM (Fixed Effect Mode)

\begin{tabular}{|c|c|c|c|c|}
\hline \multirow[t]{3}{*}{$\begin{array}{c}\text { Variabel } \\
\text { Independen }\end{array}$} & Model 1 & Model 2 & Model 3 & Model 4 \\
\hline & \multicolumn{4}{|c|}{ Variabel Dependen (VD) = In_Kasus_Positif } \\
\hline & $\begin{array}{c}\text { FEM SUR One } \\
\text { Way }\end{array}$ & $\begin{array}{c}\text { FEM SUR Two } \\
\text { Way }\end{array}$ & $\begin{array}{l}\text { FEM SUR One } \\
\text { Way + lag VD }\end{array}$ & $\begin{array}{c}\text { FEM SUR Two } \\
\text { Way + lag VD }\end{array}$ \\
\hline (1) & (2) & (3) & (4) & (5) \\
\hline Ln_APD & $\begin{array}{l}-0,0241^{*} \\
(-8,1580)\end{array}$ & $\begin{array}{l}-0,0648^{*} \\
(-9,8528)\end{array}$ & $\begin{array}{l}-0,0145^{*} \\
(-5,6547)\end{array}$ & $\begin{array}{c}-0,0509 \\
(-1,5797)\end{array}$ \\
\hline Ln_Korona & $\begin{array}{c}-0,0239 * \\
(-13,4217)\end{array}$ & $\begin{array}{l}-0,0464^{*} \\
(-1,9878)\end{array}$ & $\begin{array}{c}-0,0205^{*} \\
(-12,8206)\end{array}$ & $\begin{array}{l}-0,0423^{*} \\
(-2,2538)\end{array}$ \\
\hline Ln_desinfekan & $\begin{array}{l}-0,0278 * \\
(-8,5748)\end{array}$ & $\begin{array}{c}-0,0588 \\
(-1,7194)\end{array}$ & $\begin{array}{l}-0,0287^{*} \\
(-9,7023)\end{array}$ & $\begin{array}{c}-0,0601 \\
(-1,7859)\end{array}$ \\
\hline Ln_gejalakorona & $\begin{array}{l}0,0216^{*} \\
(5,6487)\end{array}$ & $\begin{array}{r}0,0564 \\
(1,1379)\end{array}$ & $\begin{array}{l}0,0193^{*} \\
(5,4584)\end{array}$ & $\begin{array}{c}0,0481 \\
(0,9773)\end{array}$ \\
\hline
\end{tabular}




\begin{tabular}{|l|c|c|c|c|}
\hline Ln_handsanitizer & $\begin{array}{c}-0,0136^{*} \\
(-8,2364)\end{array}$ & $\begin{array}{c}-0,0245 \\
(-1,0771)\end{array}$ & $\begin{array}{c}-0,0165^{*} \\
(-9,6364)\end{array}$ & $\begin{array}{c}-0,0292 \\
(-1,2991)\end{array}$ \\
\hline Ln_masker & $\begin{array}{l}-0,0051^{*} \\
(-4,1137)\end{array}$ & $\begin{array}{c}-0,0145 \\
(-0,6616)\end{array}$ & $\begin{array}{c}-0,0036^{*} \\
(-2,4146)\end{array}$ & $\begin{array}{c}-0,0078^{*} \\
\text { Ln_Kasus_Positif (-1) }\end{array}$ \\
\hline Jumlah Observasi & 1904 & 1904 & $0,1624 *$ \\
\hline AIC & 2,0056 & 2,0276 & $1,0472)$ & $(7,0378)$ \\
\hline SIC & 2,1222 & 2,3046 & 2,0769 & 1870 \\
\hline Adjusted R-squared & 0,4976 & 0,2839 & 0,5126 & 2,0858 \\
\hline
\end{tabular}

Keterangan : $*$ signifikan pada alpha $=5 \%$

Berdasarkan tabel 1, model yang digunakan adalah Fixed Effect Model (FEM) setelah sebelumnya melakukan Uji Chow dan Uji Hausman. Model 1 adalah model FEM one way error component dan bertujuan untuk mengontrol efek tetap individu (provinsi). Model 2 adalah FEM two way error component dan model ini bertujuan untuk mengontrol efek tetap individu (provinsi) dan waktu. Adapun model 3 sama seperti model 1 tetapi ditambah dengan memasukkan lag dari variabel dependen. Sementara model 4 sama seperti model 2 tetapi dengan menambahkan lag dari variabel dependen. Berdasarkan keempat model di atas model yang paling baik dapat dilihat dari nilai Akaike Information Criterion (AIC) dan Schwarz Information Criterion (SIC) yang paling kecil dan Adjusted $R$-square yang paling besar (Fathurahman, 2009). Model yang paling baik adalah model tanpa time fixed effect yaitu, model 1 dan model 3. Dalam model 1, ketika masyarakat memiliki keterkaitan akan pencarian informasi mengenai APD meningkat sebesar 1 persen maka kasus positif corona akan menurun sebesar 0,0241 persen tentunya pengertian ini tidak serta merta secara harfiah namun adanya keterkaitan masyarakat akan informasi APD ini menunjukkan masyarakat semakin sadar akan kepatuhan terhadap protokol kesehatan salah satunya menggunakan Alat Pelindung Diri (APD). Kemudian variabel pencarian kata korona juga signifikan, hal ini menunjukkan ketika masyarakat mempunyai keinginan untuk menggali lebih dalam mengenai virus "korona" meningkat sebesar 1 persen maka kasus positif korona akan menurun sebesar 0,0239 persen. Seperti halnya penelitian yang dilakukan oleh Kebede (2020) di Ethiopia pengetahuan dasar masyarakat mengenai COVID-19, penyebaran dan cara penularannya sangat menunjukkan kesadaran masyarakat terhadap penyebaran virus ini. Selanjutnya variabel desinfektan menunjukkan ketika masyarakat mencari informasi berkaitan dengan desinfektan, hal ini berkaitan dengan salah satu cara memutus rantai penyebaran COVID-19. Ketika hal ini dilakukan dan pencarian informasi meningkat 1 persen maka perilaku pemakaian desinfektan akan memutus rantai penyebaran COVID-19 dan kasus positif akan turun sebesar 0,0278 persen. Hal ini seperti dijelaskan oleh Larasati dan Haribowo (2020) bahwa penggunaan antiseptik dan desinfektan untuk mencegah penularan COVID-19 efektif bila pemilihannya tepat serta digunakan sesuai dengan peruntukannya. Lebih lanjut lagi karena pencarian informasi 
mengenai gejala corona menunjukkan awareness yang dimiliki masyarakat terkait gejala yang muncul, ketika informasi yang dicari ini meningkat sebesar 1 persen maka kasus positif corona akan meningkat sebesar 0,0216 persen dalam artian masyarakat ketika memiliki gejala-gejala yang mirip dengan orang yang terinfeksi COVID-19 harapannya langsung memeriksakan diri dan cepat terdeteksi. Selanjutnya berkaitan dengan pencarian informasi hand sanitizer yang merupakan salah satu barang yang diperlukan untuk menghindarkan tangan kita dari virus maupun kuman. Ketika pencarian informasi ini meningkat sebesar 1 persen maka kasus positif corona akan turun sebesar 0,0136 persen. Pencarian informasi mengenai hand sanitizer menunjukkan awareness masyarakat terhadap pemutusan rantai penyebaran virus corona. Penelitian yang dilakukan oleh Elisanti et al (2020), penggunaan hand sanitizer dengan kadar alkohol minimal 70 persen memiliki efektifitas tinggi dalam membunuh virus ini sebesar 99,05 persen. Kemudian variabel masker juga signifikan, seperti yang kita tahu masker diwajibkan untuk dikenakan oleh masyarakat kemanapun pergi. Hal ini juga menunjukkan kesadaran masyarakat tentang pentingnya mematuhi protokol kesehatan. Ketika masyarakat melakukan pencarian terkait "masker" meningkat sebesar 1 persen maka kasus positif corona akan menurun sebesar 0,0051 persen. Lebih lanjut, WHO (2020) menjelaskan Masker dapat digunakan baik untuk melindungi orang yang sehat (dipakai untuk melindungi diri sendiri saat berkontak dengan orang yang terinfeksi) atau untuk mengendalikan sumber (dipakai oleh orang yang terinfeksi untuk mencegah penularan lebih lanjut). Namun, penggunaan masker saja tidak cukup memberikan tingkat perlindungan atau pengendalian sumber yang memadai. Karena itu, langkah-langkah lain di tingkat perorangan dan komunitas perlu juga diadopsi untuk menekan penyebaran virus-virus saluran pernapasan. Terlepas dari apakah masker digunakan atau tidak, kepatuhan kebersihan tangan, penjagaan jarak fisik, dan langkah-langkah pencegahan dan pengendalian infeksi (PPI) lainnya sangat penting untuk mencegah penularan COVID-19 dari orang ke orang.

Model 3 merupakan indikasi awal mengenai sifat dinamis dari variabel dependen. Hasil model 3 menunjukkan bahwa lag variabel dependen signifikan, yang menyatakan bahwa adanya kasus pada hari sebelumnya turut menyumbang peningkatan kasus terinfeksi positif corona pada hari tertentu. Pada model 3 lag sebesar 0,1624 menunjukkan kecepatan penyebaran kasus COVID-19. Adanya sifat dinamis ini jika dipakai hasil model 3, Gujarati dan Porter (2008) menyebutkan akan menimbulkan masalah endogenitas karena memunculkan korelasi dengan error, sehingga estimasi klasik least square tidak dapat diaplikasikan. Verbeek (2004) menyebutkan jika hasil ini dipaksakan akan maka akan menghasilkan estimasi parameter yang tidak konsisten dan bias, sekalipun error tidak berkorelasi serial. Untuk mengatasi permasalahan ini maka digunakan First Difference (FD)-GMM Regresi Panel Data Dinamis. Adapun hasil dari estimasi FD-GMM adalah sebagai berikut.

Tabel 2. Hasil Regresi Data Panel Dinamis FD-GMM

\begin{tabular}{|c|c|c|c|}
\hline \multirow{2}{*}{$\begin{array}{c}\text { Variabel } \\
\text { Independen }\end{array}$} & \multicolumn{3}{|l|}{ Variabel Dependen (VD) = In_Kasus_Positif } \\
\cline { 2 - 4 } & Koefisien & z-statistics & p-value \\
\hline$(1)$ & $(2)$ & $(3)$ & $(4)$ \\
\hline Ln_Kasus_Positif (-1) & $0,1612^{*}$ & 4,92 & 0,0110 \\
\hline Ln_APD & $-0,0537^{*}$ & $-7,25$ & 0,0000 \\
\hline Ln_Korona & $-0,0289 *$ & $-5,19$ & 0,0000 \\
\hline
\end{tabular}




\begin{tabular}{|c|c|c|c|}
\hline Ln_desinfekan & $-0,0479 *$ & $-10,58$ & 0,0000 \\
\hline Ln_gejalakorona & 0,0419* & 3,77 & 0,0000 \\
\hline Ln_handsanitizer & $-0,0105^{*}$ & $-5,51$ & 0,0000 \\
\hline Ln_masker & 0,0032 & 1,12 & 0,3070 \\
\hline \multicolumn{4}{|c|}{ Arellano-Bond test (z-test) } \\
\hline $\mathrm{AB} \mathrm{m}_{1}$ & \multicolumn{3}{|c|}{$-3,4427 *$ (Tolak H0) } \\
\hline $\mathrm{AB} \mathrm{m}_{2}$ & \multicolumn{3}{|c|}{ 1,3218 (Gagal Tolak H0) } \\
\hline \multicolumn{4}{|c|}{ Sargan Test } \\
\hline Chi-square & \multicolumn{3}{|c|}{ 20,6438 (Gagal Tolak H0) } \\
\hline
\end{tabular}

Keterangan : * signifikan pada alpha $=5 \%$

Hasil tabel 2 menunjukkan bahwa, hasil Arellano-Bond test pada tingkat signifikansi 5 persen nilai $A B m_{1}(-3,4427)$ signifikan menolak $H 0$ dan nilai $A B m_{2}(-1,1524)$ gagal menolak HO. Hasil tersebut menunjukkan bahwa estimator yang diperoleh sudah konsisten. Adapun uji sargan yang gagal tolak HO menunjukkan estimasi valid. Dari ketujuh variabel yang digunakan 6 variabel yang positif kecuali variabel masker. Dari hasil FD-GMM menunjukkan adanya perbedaan hasil untuk variabel yang signifikan. Adapun untuk interpretasi masing-masing variabel yang signifikan tidak jauh berbeda dengan interpretasi hasil estimasi FEM sebelumnya. Misalnya variabel pencarian APD yang signifikan dengan koefisien -0,0537 menunjukkan bahwa ketika masyarakat mencari informasi tentang APD maka kasus positif corona dapat ditekan sebesar 0,0537 persen bukan bermakna secara harfiah. Namun hubungan ini menunjukkan kesadaran dan pemahaman masyarakat tentang penggunaan APD dalam melaksanakan kegiatan dalam situasi pandemi ini. Lebih lanjut lagi variabel mengenai pencarian informasi terkait COVID-19 yang signifikan sekali lagi memperkuat diskusi kita sebelumnya tentang pentingnya kesadaran sebelumnya dan pendidikan masyarakat tentang langkah-langkah perlindungan terhadap virus Corona.

\section{KESIMPULAN}

Dari hasil dan pembahasan diatas maka dapat disimpulkan bahwa pencarian informasi berkaitan dengan COVID-19 baik metode dan bahan yang digunakan untuk menekan penyebaran COVID-19 menunjukkan kesadaran (awareness) yang dimiliki masyarakat. Terdapat 7 variabel yang digunakan dan 6 variabel mengenai informasi yang dicari terkait COVID-19 yang signifikan menggunakan analisis data panel FEM SUR yaitu, APD, korona, hand sanitizer, gejala corona, desinfektan, masker. Analisis mengenai efek tetap individu dan efek tetap waktu menunjukkan model lebih baik menggunakan efek tetap individu (one way error component). Adanya efek dinamis dari variabel dependen maka digunakan regresi data panel dinamis FD- 
GMM yang menunjukkan data estimasi lebih baik dan terdapat 6 variabel yang signifikan yaitu, APD, korona, hand sanitizer, gejala corona, desinfektan, dan lag variabel dependen.

Saran dari hasil penelitian ini adalah untuk memutus rantai penularan COVID-19 diperlukan adanya kesadaran dan pendidikan kepada masyarakat mengenai langkah-langkah yang dapat dilakukan terkait perlindungan terhadap virus Corona, pemerintah menetapkan regulasi yang jelas dan ketat agar masyarakat mematuhi protokol kesehatan yang ada. Pelacakan dan tracing melalui data mobile (Google) dapat dilakukan untuk melacak orang yang terpapar virus Corona.

\section{DAFTAR PUSTAKA}

Baltagi, B H. (2011). Econometrics Fifth Edition. New York: Springer Heidelberg Dordrecht London, New York.

Brodeur A et all. (2020). COVID-19, Lockdowns and Well-Being: Evidence from Google Trends. IZA Institute of Labor Economics Discussion Paper DP No. 13204.

Doer, S dan Gambarcorta, L. (2020). Identifying regions at risk with Google Trends: the impact of Covid19 on US labour markets. Bank for International Settlements 2020, BIS Bulletin No.8.

Elisanti et al. (2020). Efektivitas Paparan Sinar UV dan Alkohol 70\% Terhadap Total Bakteri pada Uang Kertas yang Beredar di Masa Pandemi Covid-19. Jurnal Riset Kefarmasian Indonesia, Vol.2 No.2, hal 133-121

Farzanegan, M.R, Feizi, M dan Sadati, S.M. (2020). Google It Up! A Google Trend-based Analysis of COVID-19 Outbreak in Iran. Joint Discussion Paper Series in Economics No.17-2020, 1-16.

Fathurahman, M. (2009). Pemilihan Model Regresi Terbaik Menggunakan Metode Akaike Information Criterion dan Schwarz Information Criterion. Jurnal Informatika Mulawarman, Vol.4 No.3 September 2009, hal 37-41

Gujarati, D.N dan Porter D.C. (2008). Basic Econometrics Fifth Edition. New Yok: McGraw-Hill/Irwin.

Kebede, Y. (2020). Knowledge, perceptions and preventive practices towards COVID-19 early in the out break among Jimma university medical center visitors, South west Ethiopia. Journal Plos One-China, 21 May 2020, page 1-15.

Larasati, AL dan Hariwibowo, C. (2020). Penggunaan Desinfektan dan Antiseptik pada Pencegahan Penularan Covid-19 di Masyarakat. Majalah Farmasetika Vol.5 No.3, hal 137-145

Pandey, S dan Bright, CL. (2008). What are degree of freedom ?. National Association of Social Worker, Journal Social Work Research Vol.32, No.2, page 119-128

Pergub No.41 tahun 2020 tentang Pengenaan Sanksi Terhadap Pelanggaran Pelaksanaan Pembatasan Sosial Berskala Besar Dalam Penanganan Coronavirus Disease 2019 (Covid-19) Di Provinsi Daerah Khusus Ibukota Jakarta

Pergub No.51 tahun 2020 tentang Pelaksanaan Pembatasan Sosial Berskala Besar Pada Masa Transisi Menuju Masyarakat, Sehat, Aman dan Produktif.

Riyanto, AD. (2014). Pemanfaatan Google Trends Dalam Penentuan Kata Kunci Sebuah Produk Untuk Meningkatkan Daya Saing Pelaku Bisnis di Dunia Internet. Prosiding Seminar Nasional Informatika 2014, UPN "Veteran" Yogyakarta, 12 Agustus 2014.

Verbeek, Marno. (2004). A Guide to Modern Econometrics 2nd Edition. England: John Wiley and Sons.

WHO.(2020). Anjuran mengenai penggunaan masker dalam konteks COVID-19. Panduan Interim, 5 Juni 2020

Yunus, NR dan Rezki, A. (2020). Kebijakan Pemberlakuan Lockdown Sebagai Antisipasi Penyebaran Coronavirus Covid-19. Jurnal Sosial \& Budaya Syar-i, Vol. 7 No. 3 (2020), pp.227-238. 